\title{
What are the important risk factors for the obesity in the children three to six years of age: A cross-sectional study
}

\section{Üç-altı yaş arasındaki çocuklarda obezite için önemli risk faktörleri nelerdir: Kesitsel bir çalışma}

\author{
Pmar EDEM ${ }^{1}$, Özlem ÜZÜM² ${ }^{2}$, Tolga İNCE ${ }^{3}$, Nur ARSLAN ${ }^{4}$, Türkan GÜNAY ${ }^{5}$, Adem AYDIN ${ }^{3}$ \\ ${ }^{1}$ Dokuz Eylül Üniversitesi Tıp Fakültesi Çocuk Sağlı̆̆ı ve Hastalıkları Anabilim Dalı, Pediatrik Nöroloji Ünitesi, İzmir, Türkiye

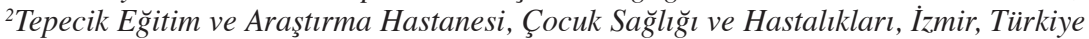 \\ ${ }^{3}$ Dokuz Eylül Üniversitesi Tıp Fakültesi Çocuk Sağlığı ve Hastalıkları Anabilim Dalı, Sosyal Pediatri Ünitesi, İzmir, Türkiye \\ ${ }^{4}$ Dokuz Eylül Üniversitesi Tıp Fakültesi Çocuk Să̆lı̆̆ ve Hastalıkları Anabilim Dalı, Çocuk Metabolizma ve Beslenme Ünitesi, İzmir, Türkiye \\ ${ }^{5}$ Dokuz, Eylül Üniversitesi Tıp Fakültesi Halk Sağlı̆̆ Anabilim Dalı, İzmir, Türkiye
}

\section{ABSTRACT}

\begin{abstract}
Objective: Overweight and obesity comprise one of the most serious public health problems of the 21 st century. The aim of this study is to investigate the incidence of overweight and obesity in an age group of 3-6 years in central towns of İzmir Metropolitan City and to examine the risk factors of obesity.

Methods: A total of 413 children were reached in this cross-sectional study. A questionnaire was completed with families concerning sociodemographic status, perinatal and growth factors, dietary habits, screen time, attendance to a daycare center or school and familial overweight and obesity. Weight and length of the children were measured, BMI values were calculated. Statistical analyses were performed using chi-square test and logistic regression model.

Results: In our study group, whose mean age was $56.7 \pm 9.3$ months, prevalence of overweight and obesity were $10.4 \%$ and $13.1 \%$, respectively. Gender was not significantly related with overweight and obesity $(\mathrm{p}=0.850)$. Birth weight $(\mathrm{p}=0.045)$, weight at one year of age $(\mathrm{p}<0.001)$, regular meal consumption $(\mathrm{p}=0.019)$, attendance to a daycare center or school $(\mathrm{p}=0.016)$, paternal BMI values $(\mathrm{p}<0.001)$ and absence of health insurance $(\mathrm{p}=0.031)$ were significantly related with childhood overweight and obesity. When we evaluated using logistic regression model, weight at one year of age $(p=0.001)$, attendance to a daycare center or school $(p=0.006)$, absence of siblings $(p=0,017)$ and absence of health insurance $(\mathrm{p}=0.048)$ were documented as risk factors for obesity too.

Conclusion: Present study suggests that educational programs about regular sporting activity and complementary nutrition like breast feeding programs; are necessary for both parents and children.
\end{abstract}

Keywords: Pediatric obesity, prevalence, risk factors

ÖZ

Amaç: Aşırı kilolu olmak ve obezite, 21. yüzyılın en ciddi halk sağlığı sorunlarından birini oluşturur. Bu çalışmanın amacı, İzmir metropolitan merkez ilçelerindeki sağıklı 3-6 yaş grubunda aşırı kilolu ve obezitenin görülme sıklığını araştırmak ve obezitenin risk faktörlerini incelemektir.

Yöntem: Bu kesitsel çalışmada toplam 413 çocuğa ulaşılmıştır. Ailelerle sosyodemografik durum, perinatal ve büyüme faktörleri, diyetsel davranışlar, ekran süresi, gündüz bakım veya okula devam etme ve ailevi aşırı kiloluluk ve obezite hakkında anket formu dolduruldu. Çocukların ağırlıkları ve boyları ölçüldü, BMI değerleri hesaplandı. İstatiksel analizler ki-kare testi ve lojistik regresyon modeli kullanılarak yapıldı.

Bulgular: Yaş ortalaması $56,7 \pm 9,3$ ay olan çalışma grubumuzda aşırı kilolu ve obezite prevalansı sırasıyla \%10,4 ve \%13,1 idi. Cinsiyet aşırı kilolu ve obezite ile anlamlı olarak ilişkili bulunmadı $(p=0,850)$. Doğum ağırlığı $(p=0,045)$, bir yaştaki vücut ağırlığı $(p<0,001)$, düzenli yemek tüketimi $(p=0,019)$, anaokulu veya kreşe gitmek $(p=0,016)$, baba BMI değerleri $(p<0,001)$ ve sağhık sigortası yokluğu $(p=0,031)$ çocukluk çağı aşırı kilolu ve obezite ile anlamlı olarak ilişkili bulundu. Lojistik regresyon modeli ile değerlendirildiğinde bir yaştaki vücut ağırlığı $(p=0,001)$, anaokulu veya kreşe gitmek $(p=0,006)$, kardeş yokluğu $(p=0,017)$ ve sağlık sigortası yokluğu $(p=0,048)$ obezite için de risk faktörleri olarak değerlendirildi.

Sonuç: Bu çalışmada, düzenli spor etkinliği ve emzirme programları gibi tamamlayıcı beslenme ile ilgili eğitim programlarının, hem ebeveynler hem de çocuklar için gerekli olduğunu göstermiştir.

Anahtar kelimeler: Çocuk obez, prevelans, risk faktörleri
Alındığı tarih: 30.04 .2018

Kabul tarihi: 27.06 .2018

Yazışma adresi: Uzm. Dr. Özlem Üzüm, Tepecik Eğitim ve Araştırma Hastanesi, Çocuyk Sağlığı ve Hastalıkları, İzmir - Türkiye

e-mail: baspinarozlemm@hotmail.com 


\section{INTRODUCTION}

Obesity is an energy metabolism disorder resulting from excess fat deposition in the body. It leads to physical and mental problems due to interactions of genetic, environmental, developmental, behavioral factors ${ }^{(1,2)}$. The prevalence of obesity in children is increasing all over the world. The World Health Organization (WHO) reports that the number of overweight children under the age of five reaches 22 million worldwide ${ }^{(3)}$. According to the National Health and Nutrition Survey (NHANES) results in the United States, between 1988-94 and 2003-04, the overweight rate for the 2-5 age group increased from $7.2 \%$ to $13.9 \%$ and the prevalence of obesity among school-aged children (6 to 11 years) and adolescents (12 to 19 years) increased dramatically between 1976-1980 and 2013-2014 from 6.5\% to $19.6 \%$ in children and from $5.0 \%$ to $20.6 \%$ in adolescents. ${ }^{(3,4)}$. In Turkey, the prevalence rates of overweight, and obesity in the age range of 6-18 years vary between $10.3-17.6 \%$, and $1.9-7.8 \%$, respectively, and the prevalence of obesity between 3-6 years is $13.8 \%{ }^{(5,6)}$.

It is known that $40 \%$ of preadolescent overweight children continue to gain weight during puberty, and $75-85 \%$ of them grow up as obese adults ${ }^{(7)}$. Similarly, it has been shown that more than one third of overweight children become obese adults ${ }^{(8)}$. If childhood obesity reaches to adulthood then it leads to serious increases in morbidity and mortality due to complications such as metabolic syndrome, type 2 diabetes, hypertension, hyperlipidemia, cardiovascular disease and certain types of cancers (colon, breast, gall bladder, and endometrium). The fact that most of these complications are preventable indicates that obesity is a health problem that should be considered even from childhood ${ }^{(9,10)}$.

The aim of this study is to investigate the incidence of overweight and obesity in a group of healthy three-to six-year-olds in İzmir Metropolitan Central Districts and to examine the risk factors of obesity.

\section{MATERIAL and METHODS}

\section{Study population}

Study data were collected in a cross-sectional study performed between July-September 2015 from 3-6 year-old children in 11 districts of İzmir. A total of 413 children were reached during the study period. Eight children were excluded who had a chronic disease associated with obesity or history of drug use for

Table 1. Questionnaires.

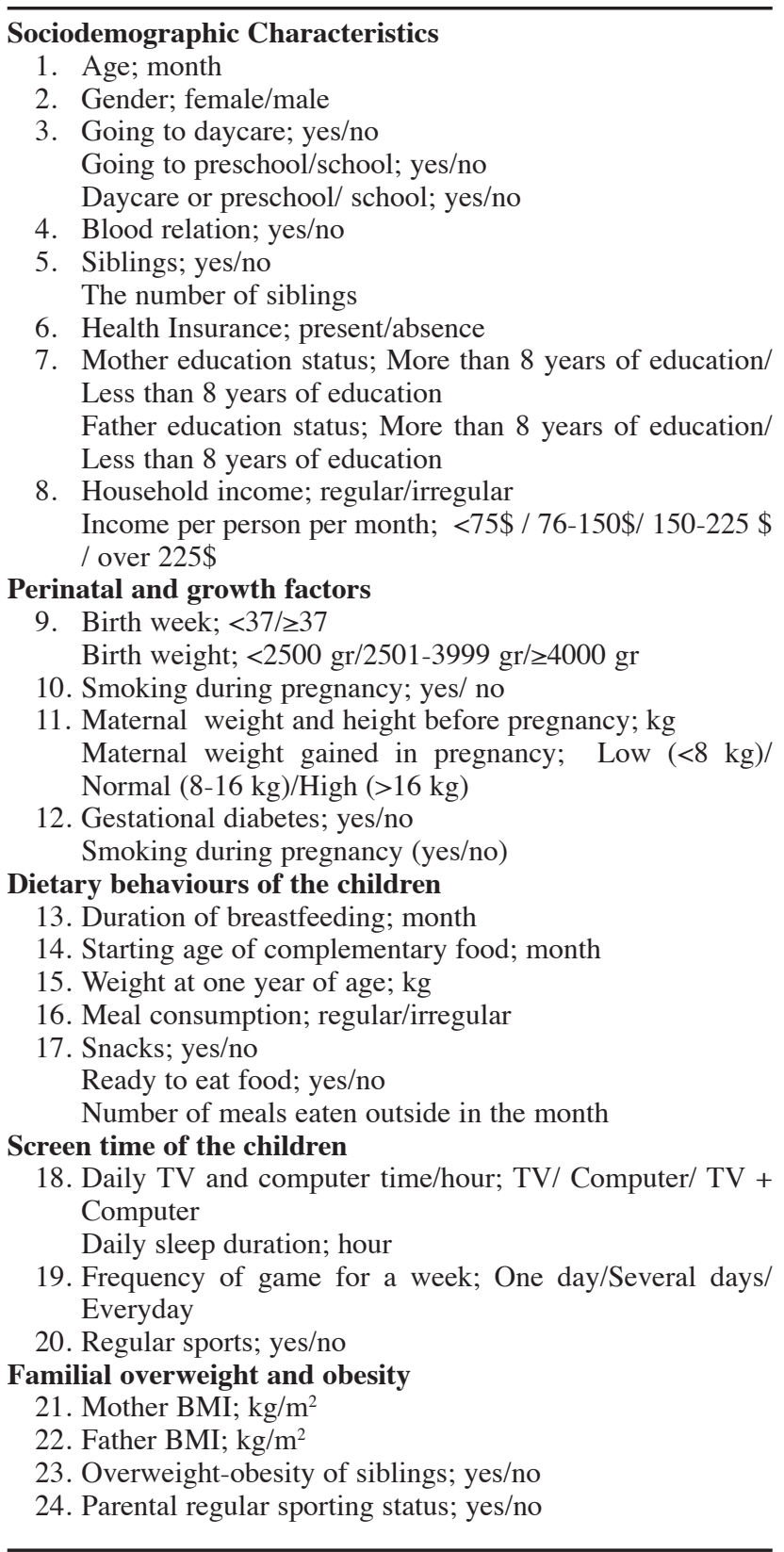


epilepsy (valproic acid) ( $\mathrm{n}=1)$, juvenile idiopathic arthritis $(n=1)$ congenital hypothyroidism $(n=3)$, chromosome anomaly $(n=1)$, motor mental retardation $(n=1)$, and cystinuria $(n=1)$. The study was conducted with a total of 405 children.

Permission for this study was granted by Dokuz Eylül University Ethics Committee and the Turkish Public Health Institution. Informed consent was received from all patients. Financial support was not received.

Questionnaires and anthropometric measurements

A questionnaire consisting of 24 questions was filled out by the families. The items included: sociodemographic status, perinatal and growth factors, dietary behaviors, screen time, familial overweight and obesity (Table 1). Birth weight according to birth week (SGA, AGA and LGA) was calculated for children ${ }^{(11)}$. Maternal weight gained in pregnancy was assessed according to the guidelines published by the Institute of Medicine (IOM) of the National Academies in 2009. Children weighing less than the recommended weight range was grouped in a smaller for their age, and over 16 kilograms of weight was categorized as overweight ${ }^{(12)}$. Maternal BMI before pregnancy was calculated by dividing the body weight by the square meter of the height ${ }^{(13)}$.

\section{Definition of overweight and obesity}

Children's weight and height were measured by the same researcher during the study. Obesity was determined according to BMI. The BMI was calculated by dividing the body weight by the square meter of the height. Body weight, body size, and BMI percentile values were calculated using the growth curves and percentiles for girls and boys aged 2-20 recommended by CDC (Centers for Disease Control and Prevention) recommended (Table 2) ${ }^{(13)}$.

Table 2. BMI percentile classification recommended by CDC ${ }^{(13)}$.

\begin{tabular}{lc}
\hline Percentile interval & Weight status by age \\
\hline$<5$ & Weak \\
$5-84.9$ & Normal \\
$85-94.9$ & Over-weight \\
$\geq 95$ & Obese \\
\hline
\end{tabular}

Abbreviations: BMI, body mass index

\section{Statistical analysis}

Statistical analysis was performed using the SPSS (Statistical Packages for the Social Sciences) Software 16.0 (Chicago, IL, USA), chi-square test and logistic regression model. If numerical data fitted to the normal distribution, mean \pm standard deviations were calculated. The Mann-Whitney $U$ test was used in order to compare the variables that did not fit to the normal distribution. The definitive chi-square test was used for the numerical variables, while Student's t-test for the numeric variables which fitted to the normal distribution. Odds ratios (ORs) were calculated for factors that cause risk of overweight and obesity. Statistical significance was accepted as $p<0.05$ for all tests.

\section{RESULTS}

The study was conducted with a total of 405 children, while girls, and boys consisted of 48.0, and 52\% of the study population, respectively. In our study population prevalence rates of preterm birth (13.2\%), low birth weight $(7.8 \%)$, and $14.3 \%$ of mothers informed that they smoked during pregnancy. Gestational diabetes was diagnosed in $6.9 \%$ of the mothers. Mean duration of breastfeeding was $14.4( \pm 8.9)$ months and mean age of the starting age of complementary food was $5.4( \pm 2.2)$ months. It was observed that children spent $3.3( \pm 2.0)$ hours watching television, $0.7( \pm 1.1)$ hours surfing on the internet and slept for $10.3( \pm 1.2)$ hours a day. It was determined that the majority of the children $(73.1 \%)$ eat snacks, and more than half of them $(52.1 \%)$ consumed fast food. Approximately

Table 3. The distribution of BMI value according to the gender.

\begin{tabular}{lccccc}
\hline & \multicolumn{4}{c}{ BMI groups; $\mathbf{n , ( \% )}$} & \\
\cline { 2 - 5 } Gender & Weak & Normal & Over-weight & Obese & Total \\
\hline \multirow{2}{*}{ Boys } & 28 & 119 & 17 & 27 & 191 \\
& $(14.7)$ & $(62.3)$ & $(8.9)$ & $(14.1)$ & $(100)$ \\
Girls & 41 & 122 & 25 & 26 & 214 \\
& $(19.2)$ & $(57.0)$ & $(11.7)$ & $(12.1)$ & $(100)$ \\
Total & 69 & 241 & 42 & 53 & 405 \\
& $(17.0)$ & $(59.5)$ & $(10.4)$ & $(13.1)$ & $(100)$ \\
\hline
\end{tabular}

Abbreviations: BMI, body mass index 
Table 4. Some features of children and parents.

\begin{tabular}{|c|c|c|c|c|}
\hline & $\begin{array}{l}\text { Total } \\
\text { n }(\%)\end{array}$ & $\begin{array}{c}\text { Weak + Normal Group } \\
\text { n }(\%)\end{array}$ & $\begin{array}{c}\text { Overweight }+ \text { Obese group } \\
\text { n }(\%)\end{array}$ & $\mathbf{p}$ \\
\hline \multicolumn{5}{|l|}{ Health Insurance } \\
\hline - Present & $378(95)$ & $292(77.2)$ & $86(22.8)$ & 0.031 \\
\hline - Absence & $20(5)$ & $11(55)$ & $9(45)$ & \\
\hline \multicolumn{5}{|l|}{ Going to preschool/school (\%) } \\
\hline - Yes & $64(15.8)$ & $41(64.1)$ & $23(35.9)$ & 0.016 \\
\hline - No & $340(84.2)$ & $268(78.9)$ & $72(21.1)$ & \\
\hline \multicolumn{5}{|l|}{ Birth weight (\%) } \\
\hline$\bullet<2500 \mathrm{~g}$ & $31(7.8)$ & $28(90.3)$ & $3(9.7)$ & 0.152 \\
\hline - $2501-3999 \mathrm{~g}$ & $329(82.9)$ & $246(74.8)$ & $83(25.2)$ & \\
\hline$\cdot \geq 4000 \mathrm{~g}$ & $37(9.3)$ & $28(75.7)$ & $9(24.3)$ & \\
\hline - median (SS), g & 397 & $3263.3 \pm 514.1$ & $3381.8 \pm 456.2$ & 0.045 \\
\hline Weight at one year of age [median $(\min ; \mathrm{max}), \mathrm{kg}]$ & 297 & $10(5 ; 15)$ & $11(5.5 ; 16)$ & $<0.001$ \\
\hline \multicolumn{5}{|l|}{ Meal consumption $(\%)$} \\
\hline - Regular & $288(71.3)$ & $212(73.6)$ & $76(26,4)$ & 0.019 \\
\hline - Irregular & $116(28.7)$ & $98(84.5)$ & $18(15,5)$ & \\
\hline Father BMI [Median (min;max), kg/m²] & 381 & $26 \pm 3.6$ & $27.7 \pm 4.2$ & $<0.001$ \\
\hline
\end{tabular}

Abbreviations: BMI, body mass index

one third of the parents completed more than 8 years of schooling (mothers: $28.6 \%$, fathers: $34.3 \%$ ) and the majority of them was at low and middle-income levels $(66.8 \%)$.

It was found that $13.1 \%$ of children were obese, $10.4 \%$ of them overweight. There was no significant difference between genders $(\mathrm{p}=0.435)$ (Table 3$)$.

The variables in the questionnaire were compared by creating two groups as weak + normal children and overweight + obese children. The mean age of the children was $56.7 \pm 9.3$ months. The mean age of the weak + normal group was 56.2 months, and the overweight + obese group 58.3 months. A statistically significant difference was not observed between mean ages of both groups ( $\mathrm{p}=0.057)$.

Absence of health insurance, attendance to nursery /school and the mean birth weight were found significantly higher in overweight + obese group compared to weak+normal group (Table 4). Median duration of breastfeeding, and child's age at starting complementary food were similar in both groups of breastfed weak + normal, and overweight + obese children (14 vs 15, and 6 vs 6 months, respectively). Weights of one-year old infants, and the percentage of children eating regular meals were significantly higher in the overweight + obese group (Table 4). The median duration of time spent on TV was similar
( 3 hours) in both groups and $85.6 \%$ of total children had not regular sporting habits. Furthermore, BMIs of fathers were significantly higher in the overweightobese group and $76.5 \%$ of parents did not have regular sporting habits like children.

To clarify the interaction of variables; birth week, birth weight, smoking during pregnancy, maternal BMI and weight before pregnancy, maternal weight gained during pregnancy, meal consumption, snacks, time spent every day for TV watching, surfing on internet and sleeping, maternal and paternal BMI values, parental education status were adjusted in

Table 5. Logistic regression analysis results.

\begin{tabular}{|c|c|c|c|}
\hline Variables & $\begin{array}{l}\text { Probability } \\
\text { Ratio (PR) }\end{array}$ & $\begin{array}{c}\% 95 \\
\text { Confidence } \\
\text { Interval (CI) }\end{array}$ & $\mathbf{p}$ \\
\hline Weight at one year of age & 1.390 & $1.139-1.698$ & 0.001 \\
\hline $\begin{array}{l}\text { Going to school } \\
\text { (Ref: not going to school) }\end{array}$ & 3.585 & $1.445-8.894$ & 0.006 \\
\hline $\begin{array}{l}\text { Health insurance } \\
\text { (Ref: absence of health } \\
\text { insurance) }\end{array}$ & 4.423 & $1.010-19.364$ & 0.048 \\
\hline Number of siblings & 0.562 & $0.350-0.903$ & 0.017 \\
\hline Coefficient & 0.010 & & 0.001 \\
\hline
\end{tabular}

Note: According to birth week, birth weight, smoking during pregnancy, maternal BMI before pregnancy, Maternal weight gained in pregnancy, meal consumption, snacks, ready to eat food, daily TV nad computer time, daily sleep duration, parental $B M I$, parental education status 
logistic regression model. The weight of the oneyear-old infant, going to daycare centers, nursery/ school, absence of siblings and health insurance were identified as significant risk factors for the overweight + obese group (Table 5).

\section{DISCUSSION}

About one-third of children and adolescents in the United States are either overweight or obese. In preschool-aged children (2 to 5 years), prevalence rates of overweight (BMI $\geq 85^{\text {th }}$ percentile) , and obesity $\left(\mathrm{BMI} \geq 95^{\text {th }}\right.$ percentile) are $22.8 \%$, and $9.4 \%$, respectively ${ }^{(4)}$. In Ankara, the prevalence of obesity was found to be $2.3 \%$ using BMI in adolescents, and children (total $n=6462$ ) aged 9-16 years ${ }^{(14)}$. In another study, in 1647 Turkish adolescents the incidence of obesity based on BMI was found to be $3.6 \%{ }^{(14)}$. In Edirne, the prevalence of obesity in 989 children aged $12-17$ years was $2.1 \%$ for females and $1.6 \%$ for males ${ }^{(16)}$. In Kirklareli, the prevalence of obesity in 727 children aged 3-6 years was found to be $13.8 \%$ and the prevalence of obesity was $17.2 \%$ in males and $10.0 \%$ in females ${ }^{(6)}$. In this study, the rate of obesity $(10.4 \%)$ was found to be relatively higher than the results obtained from the school- age children, but the overall incidence, and incidence of obesity among boys (14.1\%), and girls (12.1\%) were found to be similar to those of the preschool children in Turkey.

Birth weight is one of the most investigated risk factor in childhood obesity. There are many studies which demonstrate a significant relationship between increased birth weight and obesity, however some studies have shown lack of any correlation ${ }^{(16,17)}$. In the literature, many studies have indicated that SGA is associated with obesity complications in adults because of failure to catch up growth period, but some have found no relation between SGA and obesity. Even so the authors agreed that it does not mean SGA is protective for obesity ${ }^{(18,19)}$. LGA is more strongly associated with childhood and adult obesity ${ }^{(18,20)}$. Although in our study it was found that the birth weight was significantly higher in the overweight + obese group, there was no significant difference bet- ween the groups in birth weights according to birth weeks.

It is thought that the pregnancy-related variables (maternal BMI, maternal weight before pregnancy, maternal weight gained during pregnancy) effect obesity ${ }^{(21)}$. Ehrenberg et al. ${ }^{(22)}$ found that maternal prepregnancy BMI $>30 \mathrm{~kg} / \mathrm{m}^{2}$ would increase the risk of large-for-gestational-age (LGA) newborns by $60 \%$ compared with maternal prepregnancy BMI 19.8-25 $\mathrm{kg} / \mathrm{m}^{2}$. Li et al. ${ }^{(23)}$ demonstrated that children born to mothers with higher prepregnancy BMI had greater mean values of body weight and length/height ratio from birth to 36 months and higher prevalence of macrosomia at birth and overweight/obesity at the postnatal $12^{\text {th }}, 24^{\text {th }}$, and $36^{\text {th }}$ months. In the present study, there was no significant difference between groups in terms of pregnancy-related variables. One reason is quite small number of obese pre-pregnant women were included in the study. Besides, if greater, and equal number of children were included in both groups, statistically significant results could be obtained. The literature shows that rapid weight gain is a risk for obesity especially among children aged 2-3 years and increases the complications of obesity ${ }^{(24,25)}$. In our study, the weight at one year of age was frequently found to be significantly higher in the overweight + obesity group and this relationship continued after evaluation using logistic regression analysis including birth weight and week. This relationship indicates that eating habits which cause rapid weight gain, is a risk factor for obesity regardless of the child's birth weight and week.

In the literature analysis of data related to duration of breast feeding among 1499 children showed that the longer period of breast feeding is associated with the lower prevalence of obesity ${ }^{(9)}$. In the present study, there was no significant difference between groups. The similarity between the two groups in terms of starting age of complementary food suggests that the quality of complementary food is also an important factor in the development of obesity.

Eating snacks/fast food is a common problem among school-age children. According to studies in West Harlem, New York, America, the BMI percentiles of children living in the places where they can go 
easily to the shops for these food are proved to have significantly higher risk for obesity ${ }^{(9)}$. Eating snacks, ready-to-eat food and the number of meals eaten outside were not associated with overweight and obesity in our study. The children in this study were younger than those of other studies who had consumed readyto-eat food. This finding suggests that erroneous eating habits at home and daycare/preschool/school settings may be more effective in obesity.

According to the findings of few studies, the prevalence of obesity was found to be less for individuals who get main meals regularly and three times a day than for ones who take their meals irregularly ${ }^{(9,26)}$. Interestingly in our study, overweight and obesity were more common in children who regularly consumed food. On the other hand, this correlation was not seen in logistic regression analysis. With these results, it was concluded that the consumption of regular meals alone was not the only effective factor, the food content is also an important factor for overweight and obesity.

Current findings in the literature suggest that some sort of sedentary life activity, which we can refer to as "on-screen time", is related to obesity, but its mechanism and their interactions with physical activity are not clear yet ${ }^{(27)}$. In our study, no significant relationship was found between TV, computer overtime and obesity. It may also be appropriate to include factors such as the length of time the TV is on, the programs watched, and the time spent without watching TV. Although the on-screen time is not associated with overweight and obesity, the results are quite striking, the 3.5-4.0 hours per day at the screen time on TV is a serious risk for children. With the increase in age, screen time increases. Therefore because of its cumulative effects, the relation between screen time and overweight-obesity may probably become evident over time.

The effect of regular physical activity on the health of children and obesity is well established. Accelerometers have become more commonly used in research studies on physical activity in childhood, especially in studies performed with children aged 5-18 years ${ }^{(28)}$. In this study, regular sporting activity and playing the games with friends were investiga- ted. More than half of the children participating in the study play with their friends every day of the week; but only $14.4 \%$ were seen to have regular sporting activity without any association with overweight and obesity which indicated that the variability of the games and duration of the physical activity may play different roles in the overweight and obesity, and quantitative tests (steps/day etc.) should be more effective to determine the role of physical activities ${ }^{(2)}$.

In a study of 6-7-year-old children in Japan, it was found that obesity in sleeping at night less than 8 hours was 3 times more frequent than sleeping more than 10 hours ${ }^{(29)}$. Besides, Hiscock et al. ${ }^{(30)}$ suggested that sleeping time did not have the same role in predicting obesity until the age of seven in a more limited age group. There was no significant relationship between sleep duration and overweight-obesity in our study. This result suggests that the sleep pattern is different from that of adults in children and that changing in sleep pattern with age may have metabolic effects on sleep quality and overweight-obesity.

In this study, going to preschool or school was found to be associated with overweight- obesity, and this relationship was also maintained in logistic regression analysis. Before the research it was thought that children who went to preschool or school would gain more regular eat habits. The relationship between going to preschool/school and overweight-obesity is attributed to the fact that these children are confronted with ready-to-eat food products of which nutritional content are uncontrolled. Besides the child who begins to go to school, has his allowance which carries a risk of choosing among high energy foods.

According to the literature, the prevalence of obesity is greater in the families with higher economic levels in developing countries such as Asian countries of Singapore and Japan, and its prevalence is also higher in the children of socioeconomically poor families of developed countries ${ }^{(9,31)}$. In our country, due to the Western-type diet and sedentary life activities more common in families with high socioeconomic level, it was thought that the high socioeconomic level would be more associated with overweight and obesity. In contrast to our hypothesis, no relationship was found between the education level of the family, 
income level, family profession, and overweightobesity in childhood. It can be interpreted that unequal distribution of quality food, income level and life characteristics in our country leads to this discrepancy.

A significant relationship between absence of health insurance and overweight-obesity was found using logistic regression analysis. Although interpretation by a single parameter is difficult, it may be thought that this relationship may be due to a particularly unbalanced diet in a group without any coverage by a health insurance

In a study by Whitaker et al. ${ }^{(32)}$ on 7078 children, the researchers demonstrated that almost one-quarter of mothers and fathers were obese and over one-third of families had one obese, and $7.7 \%$ of families had 2 obese parents. Having two obese parents was a higher risk for obesity in children, and having an obese mother carried an even higher risk. They demonstrated that the only variable showing a significant correlation with parental BMI was child's age, with a stronger effect of parental BMI in the older age groups than in the 2-5-y-olds. The father's BMI was found to be associated with overweight and obesity in the present study; but the same relationship was not found in logistic regression analysis. Since the information about parents' height and weight was not based on our measurements, but parents' verbal statements, our relevant results were not precisely accurate.

Literature shows that the risk of being a single child is a risk factor and there is an inverse relationship between the number of siblings and the presence of obesity ${ }^{(33)}$. In our study, logistic regression analysis of the number of siblings showed that, increase in the number of siblings had high risk for obesity. Assuming that the multi-child families in our country have a low socioeconomic level without any health insurance, this study suggested that the risk of obesity for children with increase number of siblings, is related to failure to meet energy and balanced nutritional requirements of these children.

\section{CONCLUSION}

In this cross-sectional study, it was aimed to investigate the incidence of overweight and obesity in a group of healthy three- to six-year-old children in Central Districts of İzmir Metropolitan City and to determine the risk factors that may be related to obesity. Limitations of the study include difficulty in finding a causal relationship with variables including nutrition, physical activity and habits due to study's cross-sectional design, data collection based on verbal statements of the parents including information about their weight and height. This study showed both similar and also different results compared with the literature on obesity risk factors. The common result is that there are some mistakes that affect the future health of children in complementary nutrition. Therefore, educational programs about regular sporting activity and complementary nutritionlike breast feeding programs are necessary for both parents and children.

\section{Conflict of interest statement}

None of the authors have any conflict of interest.

\section{REFERENCES}

1. Şimşek F, Ulukol B, Berberoğlu M, Gulnar SB, Adıyaman P, Öcal G. Obesity prevalence in a primary school and a highschool in Ankara. Ankara Üniversitesi Tıp Fakültesi Mecmuası. 2005;58:163-6.

2. Yaslı G, Turhan E, Tozun M, Ahi A, Doğanay S, Ülken Y. The prevalence of obesity in third year primary school students in Karşıyaka district of İzmir province. Sürekli Tip Eğitimi Dergisi. 2014;23:168-74.

3. İnal $\mathrm{S}$, CanbulaT N. General overview on childhood obesity. Güncel Pediatri. 2013;11:27-30. https://doi.org/10.4274/Jcp.11.05

4. Ogden CL, Carroll MD, Lawman HG, et al. Trends in obesity prevalence among children and adolescents in the united states, 1988-1994 through 2013-2014. JAMA. 2016;315:2292. https://doi.org/10.1001/jama.2016.6361

5. Bereket A, Atay Z. Current status of childhood obesity and its associated morbidities in Turkey. J Clin Res Pediatr Endocrinol. 2012;4:1-7. https://doi.org/10.4274/jcrpe.506

6. Yaşar S. Kırklareli ilinde okul öncesi eğitime devam eden çocuklarda obezite prevalansının ve ebeveynlerin çocuklarının vücut ağırlığını algılama durumunun değerlendirilmesi. ht tp: // ww w.acikerisim.istanbulbilim.edu.tr/ handle/11446/1014, AccessedAugust 11, 2017.

7. Merritt RJ. Obesity. Curr Probl Pediatr. 1982;12:1-58. 
https://doi.org/10.1016/0045-9380(82)90009-3

8. Stark O, Atkins E, Wolff OH, Douglas JM. Longitudinal study of obesity in the National Survey of Health and Development. Br Med J. 1981;283:13-7. https://doi.org/10.1136/bmj.283.6283.13

9. İnanc BB, Deniz Say Şahin DS, Oğuzoncul AF, Bindak R, Mungan F. Prevalence of obesity in elementary schools in Mardin, South-Eastern of Turkey: A Preliminary Study. Balkan Med J. 2012;29:424-30. https://doi.org/10.5152/balkanmedj.2012.051

10. Savaşhan Ç, Sarı O, Aydoğan Ü. İlkokul çağındaki çocuklarda obezite görülme sıklığı ve risk faktörleri. Türk Aile Hek Derg. 2015;19:14-21. https://doi.org/10.15511/tahd.15.01014

11. Wang Y, Lim H. The global childhood obesity epidemic and the association between socio-economic status and childhood obesity. Int Rev Psychiatry. 2012;24:176-88. https://doi.org/10.3109/09540261.2012.688195

12. Institute of Medicine and NRC. Weight gain during pregnancy: reexamining the guidelines. Washington, DC: The National Academies Press; 2009.

13. http://www.cdc.gov/healthyweight/assessing/bmi/childrens_ bmi/about_childrens_bmi.html. AccessedAugust 11, 2017

14. Kanbur NO, Derman O, Kinik E. Prevalence of obesity in adolescents and the impact of sexual maturation stage on body mass index in obese adolescents. Int J Adolesc Med Health. 2002;14:61-5. https://doi.org/10.1515/IJAMH.2002.14.1.61

15. Uckun-Kitapci A, Tezic T, Firat S, et al. Obezity and type 2 diabetes mellitus: a population-based study of adolescents. J Pediatr Endocrinol Metab. 2004;17(12):1633-40. https://doi.org/10.1515/JPEM.2004.17.12.1633

16. Oner N, Vatansever U, Sari A, et al. Prevalence of underweight, overweight and obesity in Turkish adolescents. Swiss Med Wkly. 2004;134:529-33.

17. Stettler N, Zemel BS, Kumanyika S, Stallings VA. Infant weight gain and childhood overweight status in a multicenter, cohort study. Pediatrics. 2002;109:194-9. https://doi.org/10.1542/peds.109.2.194

18. Carolan Olah M, Duarte Gardea M, Lechuga J. A critical review: early life nutrition and prenatal programming for adult disease. J Clin Nurs. 2015;24:3716-29. https://doi.org/10.1111/jocn.12951

19. Schellong K, Schulz S, Harder T, Plagemann A. Birth Weight and Long-Term Overweight Risk: Systematic Review and a Meta-Analysis Including 643,902 Persons from 66 Studies and 26 Countries Globally. PLoS ONE. 2012;7:e47776. https://doi.org/10.1371/journal.pone.0047776

20. Ornoy A. Prenatal origin of obesity and their complications: Gestational diabetes, maternal overweight and the paradoxical effects of fetal growth restriction and macrosomia. Reprod Toxicol. 2011;32:205-12. https://doi.org/10.1016/j.reprotox.2011.05.002

21. Gaillard R, Durmuş B, Hofman A, Mackenbach JP, Steegers EA, Jaddoe VW. Risk factors and outcomes of maternal obesity and excessive weight gain during pregnancy. Obesity (Silver Spring). 2013;21:1046-55. https://doi.org/10.1002/oby.20088

22. Ehrenberg HM, Mercer BM, Catalano PM. The influence of obesity and diabetes on the prevalence of macrosomia. American Journal of Obstetrics and Gynecology. 2004;191:964-8. https://doi.org/10.1016/j.ajog.2004.05.052

23. Li W, Wang L, Li N, et al. Maternal Prepregnancy BMI and Glucose Level at 24-28 Gestational Weeks on Offspring's Overweight Status within 3 Years of Age. 2017. https://doi.org/10.1155/2017/7607210

24. Adair LS, Fall C, Osmond C, et al. Associations of linear growth and relative weight gain during early life with adult health and human capital in countries of low and middle income: findings from five birth cohort studies. Lancet. 2013;382:525-34. https://doi.org/10.1016/S0140-6736(13)60103-8

25. Demerath EW, Reed D, Choh AC, et al. Rapid Postnatal Weight Gain and Visceral Adiposity in Adulthood: The Fels Longitudinal Study. Obesity (Silver Spring). 2009;17(11):2060-6. https://doi.org/10.1038/oby.2009.105

26. Elgar FJ, Roberts C, Moore L, Tudor-Smith C. Sedentary behaviour,physical activity and weight problems in adolescents in Wales. Public Health. 2005;119:518-24. https://doi.org/10.1016/j.puhe.2004.10.011

27. Council on Communications and Media, Strasburger VC. Children, adolescents, obesity, and the media. Pediatrics. 2011;128:201-8. https://doi.org/10.1542/peds.2011-1066

28. Oliveira LC, FerrariI GLM, AraújoI TL, Matsuda V. Overweight, obesity, steps, and moderate to vigorous physical activity in children. Rev Saúde Pública. 2017;51:38. https://doi.org/10.1590/s1518-8787.2017051006771

29. Sekine M, Yamagami T, Handa K, et al. Dose-response relationship between short sleeping hours and childhood obesity: results of the Toyama Birth Cohort Study. Child Care Health Dev. 2002;28:163-70. https://doi.org/10.1046/j.1365-2214.2002.00260.x

30. Hiscock H, Scalzo K, Canterford L, Sleep duration and body mass index in 0-7-year olds.Wake M. Arch Dis Child. 2011;96:735-9. https://doi.org/10.1136/adc.2010.204925

31. Fernández-Alvira JM, teVelde SJ, De Bourdeaudhuij I, et al. Parental education associations with children's body composition: mediation effects of energy balance-related behaviors within the ENERGY-project. Int J Behav Nutr Phys Act. 2013;10:80. https://doi.org/10.1186/1479-5868-10-80

32. Whitaker KL, Jarvis MJ, Beeken RJ, Boniface D, Wardle J. Comparing maternal and paternal intergenerational transmission of obesity risk in a large population-based sample. Am J Clin Nutr. 2010;91:1560-7. https://doi.org/10.3945/ajen.2009.28838

33. Chen AY, Escarce JJ. Family structure and childhood obesity, Early Childhood Longitudinal Study - Kindergarten Cohort. Prev Chronic Dis. 2010;7:A50. 